\title{
Alteriqipengyuania abyssalis sp. nov., a Novel Member of the Class Alphaproteobacteria Isolated from Sponge, and Emended Description of the Genus Alteriqipengyuania
}

\author{
Sanaullah Tareen ${ }^{1,2}$, Chandra Risdian $\left.{ }^{1,3}{ }^{(}\right)$, Mathias Müsken ${ }^{4}\left[\right.$ and Joachim Wink ${ }^{1, *} \mathbb{C}$ \\ 1 Microbial Strain Collection (MISG), Helmholtz Centre for Infection Research (HZI), \\ 38124 Braunschweig, Germany; sanaullahtareen734@gmail.com or sanaullah.tareen@helmholtz-hzi.de (S.T.); \\ chandra.risdian@helmholtz-hzi.de (C.R.) \\ 2 Department of Microbiology, Balochistan University of Information Technology Engineering and \\ Management Sciences, Quetta 87300, Pakistan \\ 3 Research Unit for Clean Technology, National Research and Innovation Agency (BRIN), \\ Bandung 40135, Indonesia \\ 4 Central Facility for Microscopy, Helmholtz Centre for Infection Research (HZI), 38124 Braunschweig, \\ Germany; Mathias.Muesken@helmholtz-hzi.de \\ * Correspondence: Joachim.Wink@helmholtz-hzi.de
}

check for updates

Citation: Tareen, S.; Risdian, C.; Müsken, M.; Wink, J.

Alteriqipengyuania abyssalis sp. nov., a Novel Member of the Class Alphaproteobacteria Isolated from Sponge, and Emended Description of the Genus Alteriqipengyuania. Diversity 2021, 13, 670. https:/ / doi.org/10.3390/d13120670

Academic Editor: Ipek Kurtboke

Received: 13 October 2021

Accepted: 10 December 2021

Published: 14 December 2021

Publisher's Note: MDPI stays neutral with regard to jurisdictional claims in published maps and institutional affiliations.

Copyright: (C) 2021 by the authors Licensee MDPI, Basel, Switzerland. This article is an open access article distributed under the terms and conditions of the Creative Commons Attribution (CC BY) license (https:// creativecommons.org/licenses/by/ $4.0 /)$.

\begin{abstract}
A novel Gram-negative, aerobic, motile, lemon-yellow-colored, and non-spore-forming rod-shaped bacterium designated strain NZ-12B ${ }^{\mathrm{T}}$ was isolated in February 2021 from a sponge species (Crateromorpha) collected at the southern Kermadec Ridge, Pacific Ocean, New Zealand. Comparative 16S rRNA gene-based analyses indicated that strain NZ-12B ${ }^{\mathrm{T}}$ shared $98.58 \%, 96.44 \%$, 96.23\%, and $94.78 \% 16 \mathrm{~S}$ rRNA sequence similarity to Alteriqipengyuania lutimaris S-5 ${ }^{\mathrm{T}}$, Qipengyuania pelagi UST081027-248 ${ }^{\mathrm{T}}$, Qipengyuania citreus RE35F $/ 1^{\mathrm{T}}$, and Alteriqipengyuania halimionae CPA $^{\mathrm{T}}$, respectively. The major respiratory quinone was ubiquinone-10(Q-10). The polar lipid profile of NZ-12B ${ }^{\mathrm{T}}$ was composed of diphosphatidylglycerol, phosphatidylethanolamine, phosphatidyl-Nmethyl-ethanolamine, phosphatidylcholine, sphingoglycolipid, phosphatidylglycerol, one unknown polar lipid, three unknown phospholipids, and three unknown glycolipids. The major fatty acids of strain NZ-12B ${ }^{T}$ were $C_{18: 1} \omega 12 t, C_{16: 0}, C_{17: 1} \omega 6 c$, and $C_{14: 0} 2-O H$. Carotenoids were present. Genome mining analysis revealed a biosynthetic gene cluster encoding for the terpene biosynthesis. Pairwise ANI and $\mathrm{dDDH}$ values of strain NZ-12B $\mathrm{B}^{\mathrm{T}}$ and closely related phylogenetic neighbors were below the threshold values of $95 \%$ and $70 \%$, respectively. The DNA G+C content was $65.4 \mathrm{~mol} \%$ (by genome). Based on data obtained by a polyphasic approach, type strain NZ-12B ${ }^{\mathrm{T}}\left(=\mathrm{DSM} 112810^{\mathrm{T}}\right.$ $=$ NCCB $100841^{\mathrm{T}}$ ) represents a novel species of the genus Alteriqipengyuania, for which the name Alteriqipengyuania abyssalis sp. nov. is proposed.
\end{abstract}

Keywords: Alphaproteobacteria; Alteriqipengyuania; deep-sea; Polyphasic analysis; Qipengyuania; sponge

\section{Introduction}

The development of new antibiotics that are both safe and effective against resistant microbes is critical in combating the growing issue of antibiotic resistance [1,2]. Natural products produced by marine microbes have proven to be a valuable source of clinically important compounds. The deep sea, representing ocean depths below $1000 \mathrm{~m}$, signifies a marginally scrutinized habitat sheltering novel and yet to be discovered microorganisms. The deep sea extreme environments have equipped its microbiota with unique physiological mechanisms, a capacity to form diverse metabolites with unique structures, and a copious range of functions [3]. During the course of the study aimed at the isolation of novel bioactive compounds from deep-sea sponge-associated bacteria, we encountered a strain designated NZ-12B ${ }^{\mathrm{T}}$. The isolate was shown to be closely related to Alteriqipengyuania lutimaris $\mathrm{S}-5^{\mathrm{T}}$, a member of the family Erythrobacteraceae based on comparative $16 \mathrm{~S}$ 
rRNA gene analyses. The taxonomy of the family Erythrobacteraceae was recently revised using genome-based methods, resulting in the creation of 11 new genera within the family [4]. Creation of novel genera has resulted in the placement of Erythrobacter lutimaris into a novel genus Alteriqipengyuania. Genus Alteriqipengyuania, a member of the family Erythrobacteraceae [5], belongs to the class Alphaproteobacteria, with the description of $A l$ teriqipengyuania lutimaris as the type species [6]. At the time of writing this paper, the genus Alteriqipengyuania comprises two species with validly published names: A. halimionae CECT $9130^{\mathrm{T}}$ and A. lutimaris CECT $8624^{\mathrm{T}}$ https:/ / lpsn.dsmz.de/genus/alteriqipengyuania (accessed on 4 August 2021) [7]. Members of the family Erythrobacteraceae have been isolated from marine organisms [8], marine cyanobacterial mat, seawater, marine and mangrove sediments [9-11], solar saltern [12], ice core [13], and estuary environments [14]. The members of the family Erythrobacteraceae are Gram-negative, rod or pleomorphic coccoidshaped, pink-, red-, orange-, or yellow-pigmented, and aerobic chemoorganotrophs [15]. Identification of novel microbial species with potential industrial relevance from extreme environments provides a framework for the improvement of sequence databases and may lead to the identification of new biotechnologically relevant entities. The present work aimed to determine the taxonomic position of $\mathrm{NZ}-12 \mathrm{~B}^{\mathrm{T}}$ using a polyphasic characterization approach, including the determinations of chemotaxonomic and other phenotypic properties, a detailed phylogenetic investigation based on 16S rRNA gene sequences, and genetic analyses of genome data.

\section{Materials and Methods}

\subsection{Isolation, Cultivation and Maintenance of Bacteria}

The sponge species (Crateromorpha) was collected in February 2017 during a sample collection expedition from a depth of $1165 \mathrm{~m}$ below the ocean surface at the southern Kermadec ridge $\left(35^{\circ} 60^{\prime} \mathrm{N}, 178^{\circ} 85^{\prime} \mathrm{W}\right)$, Pacific Ocean, New Zealand. The sponge sample for bacterial isolation was washed with sterile artificial seawater (ASW) to remove the loosely bound bacterial cells and debris. Approximately $1 \mathrm{~cm}^{3}$ of the sponge tissue sample was cut with a sterile scalpel, ground using a mortar and pestle, and immediately transferred to $9 \mathrm{~mL}$ of sterile artificial seawater. Several dilutions (from $10^{-2}$ to $10^{-6}$ ) were prepared and $0.1 \mathrm{~mL}$ was spread on sea water glutamate (SWG) media containing artificial sea-water $(3.9 \%(w / v)$ of sea salt from ATI Coral Ocean), $0.1 \%$ sodium glutamate, solidified with $1.6 \%$ agar (Difco) [16]. Filter sterilized cycloheximide $(50 \mathrm{mg} / \mathrm{L})$ was added to the media after autoclaving to inhibit fungal growth. Agar plates were incubated at $30^{\circ} \mathrm{C}$ and routinely checked for observed growth under a stereomicroscope for $2-4$ weeks. The strain NZ-12B ${ }^{T}$ was purified by repeated streaking on marine agar (MA, Difco). The purified strain was preserved in marine broth 2216 (MB, Difco laboratories, BD, USA) with 50\% $(v / v)$ glycerol at $-80^{\circ} \mathrm{C}$.

Unless otherwise specified, all characteristics described hereafter are based on cultures incubated on marine agar (MA) or marine broth (MB) for three days at $30^{\circ} \mathrm{C}$. Type strains Q. pelagi NRRL $59511^{\mathrm{T}}$ and Q. citreus $\mathrm{DSM} 14432^{\mathrm{T}}$ were obtained from the northern regional research lab, USA, and the German collection of microorganisms and cell cultures DSMZ, respectively.

\subsection{Morphological, Cultural and Physiological Characterization}

Morphological observations were carried out on MA 2216 medium (Difco laboratories, $\mathrm{BD}$, USA) incubated at $30^{\circ} \mathrm{C}$ over the course of a week. Cell morphology was determined using phase-contrast microscopy and electron microscopy (SEM and negative staining TEM, Zeiss, Oberkochen, Germany). Scanning electron microscopy was performed as previously described with slight modifications [17]. In brief, bacteria were fixed in medium with subsequent addition of aldehydes ( $30 \mathrm{~min}$ in $2 \%$ glutaraldehyde final concentration, followed by $30 \mathrm{~min}$ in $5 \%$ formaldehyde final concentration). Dehydration was undertaken in a gradient series of acetone, followed by critical point drying and sputter coating with gold palladium. A Zeiss Merlin field emission SEM was used for image acquisition at 
various magnifications and a 25:75 ratio of Everhart-Thornley and Inlens detector. For transmission electron microscopy, a thin carbon film was floated on a sample drop, taken off with a grid, washed twice, and negatively stained with $4 \%$ uranyl acetate before analysis with a Zeiss Libra 120 at various magnifications.

Gram staining was performed using a Gram stain kit (Sigma-Aldrich, CA, USA) according to the manufacturer's instructions. The color of the culture was determined by comparison with RAL color code 1005 (Deutsches Institut für Gütesicherung und Kennzeichnung e.V.-Reichs-Ausschuss für Lieferbedingungen). The activities of oxidase and catalase were determined with $\mathrm{N}, \mathrm{N}$-dimethyl-p-phenylenediamine dihydrochloride and $3 \%(v / v) \mathrm{H}_{2} \mathrm{O}_{2}$ solutions, respectively. Growth under anaerobic conditions was tested on $\mathrm{MA}$ in an anaerobic chamber at $30^{\circ} \mathrm{C}$ using the Anaerocult A system, following the manufacturer's instructions. Motility was determined using the wet mount slide and hanging drop methods [18]. Growth at different temperatures $\left(4,15,20,25,30,37,44{ }^{\circ} \mathrm{C}\right)$ was determined on MA medium. Growth at $\mathrm{pH}$ 3-11 at intervals of one unit $\mathrm{pH}$ was examined in $\mathrm{MB}$ ( $\mathrm{pH}$ was confirmed after autoclaving). The requirement for and tolerance to various salt concentrations were tested on $1.6 \%$ agar medium containing (per liter) $5.9 \mathrm{~g}$ $\mathrm{MgCl}_{2}, 3.24 \mathrm{~g} \mathrm{Na}_{2} \mathrm{SO}_{4}, 1.8 \mathrm{~g} \mathrm{CaCl}_{2}, 0.55 \mathrm{~g} \mathrm{KCl}, 5.0 \mathrm{~g}$ peptone, $0.1 \mathrm{~g}$ ferric citrate, and $1.0 \mathrm{~g}$ yeast extract ( $\mathrm{pH} 7.6)$ in the presence of 2.5, 5.0, 7.5, and $10 \%(w / v) \mathrm{NaCl}$ [19].

Enzyme activities and assimilation of substrates were tested by employing API ZYM, API 20E, and API 20NE strips (Biomerieux, Marcy l'Etoile, France) and the Biolog Gen Microplate system according to the manufacturer's instructions. Carbon sources (arabinose, cellulose, fructose, inositol, mannitol, raffinose, rhamnose, sucrose, and xylose) utilization was carried out in MA medium with the addition of $1 \%$ filter-sterilized carbon sources in a micro-dilution well plate. For the antibiotic resistance test, pre-cooled agar was supplemented with filter-sterilized antibiotics with the final concentration adjusted to $50 \mu \mathrm{g} \mathrm{mL}^{-1}$ except for oxytetracycline, ampicillin, chloramphenicol, and hygromycin. The antibiotics used were polymyxin $(50 \mu \mathrm{g} / \mathrm{mL})$, gentamicin $(50 \mu \mathrm{g} / \mathrm{mL})$, oxytetracyclin $(10 \mu \mathrm{g} / \mathrm{mL})$, ampicillin $(100 \mu \mathrm{g} / \mathrm{mL})$, chloramphenicol $(30 \mu \mathrm{g} / \mathrm{mL})$, spectinomycin $(50 \mu \mathrm{g} / \mathrm{mL})$, kanamycin $(50 \mu \mathrm{g} / \mathrm{mL})$, cephalosporin $(50 \mu \mathrm{g} / \mathrm{mL})$, fusidic acid $(50 \mu \mathrm{g} / \mathrm{mL})$, bacitracin $(50 \mu \mathrm{g} / \mathrm{mL})$, thiostrepton $(50 \mu \mathrm{g} / \mathrm{mL})$, trimethoprim $(50 \mu \mathrm{g} / \mathrm{mL})$, and hygromycin $(150 \mu \mathrm{g} / \mathrm{mL})$ [20].

\section{3. $16 S$ rRNA Gene Sequence and Phylogenetic Analysis}

Molecular taxonomic characterization was performed using $16 \mathrm{~S}$ rRNA gene sequence analysis. Strain NZ-12B ${ }^{\mathrm{T}}$ was grown in MB medium for three days at $30{ }^{\circ} \mathrm{C}$. Genomic DNA was extracted using the protocol of the Nucleospin Microbial DNA kit (Macherey Nagel). The 16S rRNA gene was amplified using the primers F27 (5'-AGAGTTTGATCMTGGCTCAG$\left.3^{\prime}\right)$ and R1492 (5'-GGTTACCTTGTTACGACTT-3'). The PCR product was purified using the Nucleospin Gel and PCR clean-up kit (Macherey Nagel) following analysis of the PCR product by gel electrophoresis using a $0.8 \%(w / v)$ agarose gel at $80 \mathrm{~V}$ for $30 \mathrm{~min}$. Primers F1100 (5'-CAACGAGCGCAACCC-3'), R1100 (5'-GGGTTGCGCTCGTTG-3'), and R518 (5'CGTATTACCGCGGCTGCTGG-3' ${ }^{\prime}$, in addition to the primers used for primary PCR, were applied for sequencing of the 16S rRNA gene using a 370XL automatic sequencer from Applied Biosystems (ABI). The acquired sequences were assembled using the Bioedit program (version 7.0.5.3) [21] (http:/ / www.mbio.ncsu.edu/BioEdit/bioedit.html) (accessed on 25 July 2021). The consensus sequences were produced using the cap contig assembly function of the Bioedit sequence alignment editor version 7.0.5.3 [20]. Pairwise sequence similarities were calculated using the database of $16 \mathrm{~S}$ rRNA gene sequences from the EZBioCloud server (https: / / www.EZBioCloud.net) (accessed on 25 July 2021). Phylogenies were inferred by the GGDC web server [22] available at http:/ / ggdc.dsmz.de/ (accessed on 25 July 2021) using the DSMZ phylogenomics pipeline [23] adapted to single genes. A multiple sequence alignment was created with MUSCLE [24]. Maximum likelihood (ML) and maximum parsimony (MP) trees were inferred from the alignment with RAxML [25] and TNT [26], respectively. For $\mathrm{mL}$, rapid bootstrapping in conjunction with the autoMRE bootstopping 
criterion [27] and subsequent search for the best tree was used for MP; 1000 bootstrapping replicates were used in conjunction with tree-bisection-and-reconnection branch swapping and ten random sequence addition replicates. The sequences were checked for a compositional bias using the $\mathrm{X}^{2}$ test as implemented in PAUP. The tree was also inferred using the neighbor joining algorithm from MEGA X [28]. The topologies of the inferred tree were examined by bootstrap analyses based on 1000 replicates. The $16 \mathrm{~S}$ rRNA gene sequence of strain NZ-12B ${ }^{\mathrm{T}}$ was deposited at Genbank under accession code MZ569434.

\subsection{Chemotaxonomy}

Freeze-dried cells were used for chemotaxonomic analyses of respiratory quinones, polar lipids, and fatty acids. Cells of strain $\mathrm{NZ}-12 \mathrm{~B}^{\mathrm{T}}, \mathrm{Q}$. citreus $\mathrm{RE} 35 \mathrm{~F} / 1^{\mathrm{T}}$, and $Q$. pelagi UST081027-248 ${ }^{\mathrm{T}}$ were grown in $\mathrm{MB}$ for three days at $30^{\circ} \mathrm{C}$, harvested, and washed three times with sterile phosphate buffer saline prior to lyophilization.

Polar lipids were extracted in accordance with the procedure described by [29]. Polar lipids were separated by two-dimensional thin-layer chromatography (2D-TLC) on silica gel and five TLC plates $(10 \times 10)$ were used per isolate. Beginning with $10 \mu \mathrm{L}$ lipid extracts spotted on each plate, the solvent mixture used for the first dimension was chloroform/methanol/water (65:25:4 by vol.), and chloroform/methanol/acetic acid/water (80:12:15:4 by vol.) for the second dimension. Various reagents were used for detection of polar lipids with differing functional groups [18]. The first plate was stained with phosphomolybdic acid to detect all polar lipids. The second plate was stained with ninhydrin to detect aminolipids, followed by staining of the same plate with molybdenum blue to detect phospholipids. The third plate was stained with $\alpha$-naphthol to detect sugar-containing lipid [18]. The fourth and fifth plates were stained with anisaldehyde and dragendorff's reagents, respectively. Once stained, plates were heated at 100 to $120^{\circ} \mathrm{C}$ to visualize polar lipids, other than the plate stained with molybdenum blue and dragendorff's reagent, which was developed at room temperature.

The presence or absence of carotenoids was examined by extraction using a ternary solvent system of hexane/methanol/water mixture in a ratio of 2:1:1, respectively [30], and subsequent analysis by HR-ESI-MS (high-resolution electrospray ionization mass spectrometry). High-resolution electron spray ionization mass spectrometry (HR-ESI-MS) data were recorded on a Maxis ESI-TOF-MS spectrometer (Bruker, Bremen, Germany) equipped with an Agilent 1260 series RP-HPLC system using an Acquity C18 column $2.1 \times 50 \mathrm{~mm}, 1.7 \mu \mathrm{m}$. Solvent A was water +0.1 formic acid and solvent B was acetonitrile + 0.1 formic acid. The gradient system was $5 \%$ B for $0.5 \mathrm{~min}$, increasing to $100 \% \mathrm{~B}$ in $19.5 \mathrm{~min}$ and holding for $5 \mathrm{~min}$ at $100 \% \mathrm{~B}$ with the flow rate of $0.6 \mathrm{~mL} / \mathrm{min}$. Respiratory quinones were extracted according to the method of Minnikin et al. (1984) and were analyzed by high-performance liquid chromatography with some modifications of mobile phase and flow rate [31]. Solvent A (35\% isopropanol) and solvent B (65\% acetonitrile) were used as isocratic condition mobile phase with a flow rate of $0.3 \mathrm{~mL} / \mathrm{min}$. Fatty acids methyl esters (FAME) analysis was conducted using 6890N gas chromatography equipped with FID (flame ionization detector). Separation of the fatty acids' methyl esters was carried out with a Macherey Nagel Optima 5 column (5\% phenyl, 95\% dimethylpolysiloxane, $50 \mathrm{~m}$ length; $0.32 \mathrm{~mm}$ inner diameter, $0.25 \mu \mathrm{m}$ film thickness). Individual fatty acid methyl esters were identified by their retention time compared with standards (in-house reference standard).

\subsection{Genome Analysis}

Genomic DNA used for sequencing was extracted from axenic cultures grown for three days on MA at $30{ }^{\circ} \mathrm{C}$ using the protocol of the Nucleospin microbial DNA kit according to the manufacturer's instructions. Genome sequencing was carried out at the Sequencing facility (HZI, Braunschweig, Germany) on the Illumina MiSeq (300 bp, pairedend reads) using the NexteraXT protocol for library preparation followed by de novo assembly using a unicycler genome assembler [32]. Automated genome annotation was carried out using the NCBI Prokaryotic Genome Annotation Pipeline PGAP [33]. The 
whole-genome sequence of strain NZ-12B ${ }^{\mathrm{T}}$ was deposited at DDBJ/ENA/GenBank under the accession JAHWXP000000000. Draft genome assembly was analyzed using ContEst16S (www.ezbiocloud.net/tools/contest16s) (accessed on 19 August 2021) [34] to verify that the genome was uncontaminated. The DNA G+C content ( $\mathrm{mol} \%$ ) was determined based on whole-genome data. The genomic sequence was also uploaded to the RAST (Rapid Annotation using Subsystem Technology) server (https://rast.nmpdr. org/) (accessed on 21 August 2021) [35] and the antiSMASH (antibiotics and secondary metabolite analysis shell) server (https: / / antismash.secondarymetabolites.org/) (accessed on 21 August 2021) $[36,37]$ for metabolic reconstruction analysis and prediction of secondary metabolite gene clusters, respectively.

The phylogenomic tree was created based on the whole-genome sequence of NZ$12 \mathrm{~B}^{\mathrm{T}}$ and its closest phylogenetic hits using the type (strain) genome server (TYGS) (https://tygs.dsmz.de/) (accessed on 25 August 2021). For the phylogenomic inference, all pairwise comparisons among the set of genomes were conducted using GBDP and accurate intergenomic distances inferred under the algorithm 'trimming' and distance formula d5 [22]. One hundred distance replicates were calculated each. In silico DNA-DNA hybridization estimates were calculated using the Genome-to Genome Distance Calculator (GGDC; version 2.1) developed by Meier-Kolthoff et al. [38]. Pairwise average nucleotide identity (ANI) values between genome sequences of the closest phylogenetic relatives were calculated using the EzBioCloud server (www.ezbiocloud.net/tools/ani) (accessed on 21 August 2021) [39].

\section{Results and Discussion}

\subsection{Morphological and Physiological Characteristics}

The strain was isolated from a sponge sample obtained in February 2017 on the southern Kermadec ridge, Pacific Ocean $\left(350^{\circ} 60 / \mathrm{N}, 178^{\circ} 85 / \mathrm{W}\right)$ about $1165 \mathrm{~m}$ beneath the ocean surface. Cells of strain NZ-12B ${ }^{\mathrm{T}}$ were observed to be Gram-negative, aerobic, catalase and oxidase-positive, motile, straight rods that occur singly and in pairs and were non-spore-forming. Colonies were lemon-yellow-colored, circular, and convex with entire margins (Figure 1). Electron microscopy images of strain NZ-12B ${ }^{\mathrm{T}}$ clearly displayed the rod-shaped morphology and presence of a single polar flagellum (Figure 1). Strain $\mathrm{NZ}-12 \mathrm{~B}^{\mathrm{T}}$ grew at $15-37^{\circ} \mathrm{C}$ (optimal growth at $15-30^{\circ} \mathrm{C}$ ). No growth was shown at 4 and $44^{\circ} \mathrm{C}$. Growth was observed at $\mathrm{pH} 6-9$ (optimum at $\mathrm{pH}$ 6). Growth occurs in the presence of $0-7.5 \%(w / v) \mathrm{NaCl}$ with optimum growth at $2.5 \%(w / v) \mathrm{NaCl}$. Apart from marine agar 2216 (Difco), the strain also grew on ASW-CY medium, (Casitone $3.00 \mathrm{~g}$, $\mathrm{CaCl}_{2} \times 2 \mathrm{H}_{2} \mathrm{O} 1.36 \mathrm{~g}$, Yeast extract $1.00 \mathrm{~g}$, Agar $16.00 \mathrm{~g}$, distilled water $1000 \mathrm{~mL}, \mathrm{pH} 7.2$ ) supplemented with $39 \mathrm{~g}$ artificial sea salts. Antibiotic susceptibility test data indicated that the strain was sensitive to gentamicin, thiostrepton, chloramphenicol, kanamycin, and fusidic acid. However, it was resistant to hygromycin, trimethoprim, spectinomycin, ampicillin, oxytetracyclin, cephalosporin, bacitracin, and polymyxin. Physiological and biochemical properties of strain NZ-12B ${ }^{\mathrm{T}}$ according to API ZYM (Table S1 in Supplementary Materials), API 20E (Table S2), and API 20NE (Table S3) strips and the Biolog Gen III Microplate system (Table S4), showed strong activity for alkaline phosphatase, leucine arylamidase, valine arylamidase, cystine arylamidase, trypsin, acid phosphatase, naphtholAS-BI-phosphohydrolase, $\alpha$-glucosidase, arginine dihydrolase, and esculin hydrolysis. In contrast, no activity was observed for $\alpha$-galactosidase, $\beta$-galactosidase, $\beta$-glucuronidase, $\beta$ glucosidase, $N$-acetyl- $\beta$-glucosaminidase, $\alpha$-mannosidase, $\alpha$-fucosidase, $\beta$-galactosidase (ONPG), ornithine decarboxylase, urease, bromo-succinic acid, or mannose assimilation. Strain NZ-12B ${ }^{\mathrm{T}}$ differed from A. lutimaris KCTC $42109^{\mathrm{T}}$, Q. pelagi $\mathrm{JCM} 14468^{\mathrm{T}}$, and Q. citreus DSM $14432^{\mathrm{T}}$ in gelatinase, esculin hydrolysis, and tryptophan deaminase activities. In contrast to Q. pelagi $14468^{\mathrm{T}}$ and Q. citreus $14432^{\mathrm{T}}$, which reduce nitrate, strain $\mathrm{NZ}-12 \mathrm{~B}^{\mathrm{T}}$ was negative for nitrate reduction. Strain NZ-12B ${ }^{\mathrm{T}}$ was distinguishable from members of genus Alteriqipengyuania by certain properties. Cells of strain NZ-12B ${ }^{\mathrm{T}}$ are motile rods, whereas A. lutimaris KCTC $42109^{\mathrm{T}}$ cells are non-motile and coccoid or oval shaped. Strain NZ-12B ${ }^{\mathrm{T}}$ 
was positive for $\alpha$-glucosidase, whereas A. lutimaris KCTC $42109^{\mathrm{T}}$ and A. halimionae CPA $5^{\mathrm{T}}$ were negative for the said property. Strain NZ-12B ${ }^{\mathrm{T}}$ was positive for esterase (C4) and arginine dihydrolase, whereas A. lutimaris KCTC $42109^{\mathrm{T}}$ was negative for esterase (C4) and A. halimionae $\mathrm{CPA} 5^{\mathrm{T}}$ was negative for arginine dihydrolase. Strain $\mathrm{NZ}-12 \mathrm{~B}^{\mathrm{T}}$ was sensitive to gentamicin, whereas A. lutimaris KCTC $42109^{\mathrm{T}}$ was resistant to gentamicin. Strain NZ-12B ${ }^{\mathrm{T}}$ showed optimal growth at $\mathrm{pH} 6$, whereas A. lutimaris KCTC $42109^{\mathrm{T}}$ and A. halimionae $\mathrm{CPA}^{\mathrm{T}}$ displayed optimum growth at $\mathrm{pH}$ above 7 . Detailed comparisons of enzymatic activities between strain NZ-12B ${ }^{\mathrm{T}}$ and reference strains are shown in (Table S1-S3).

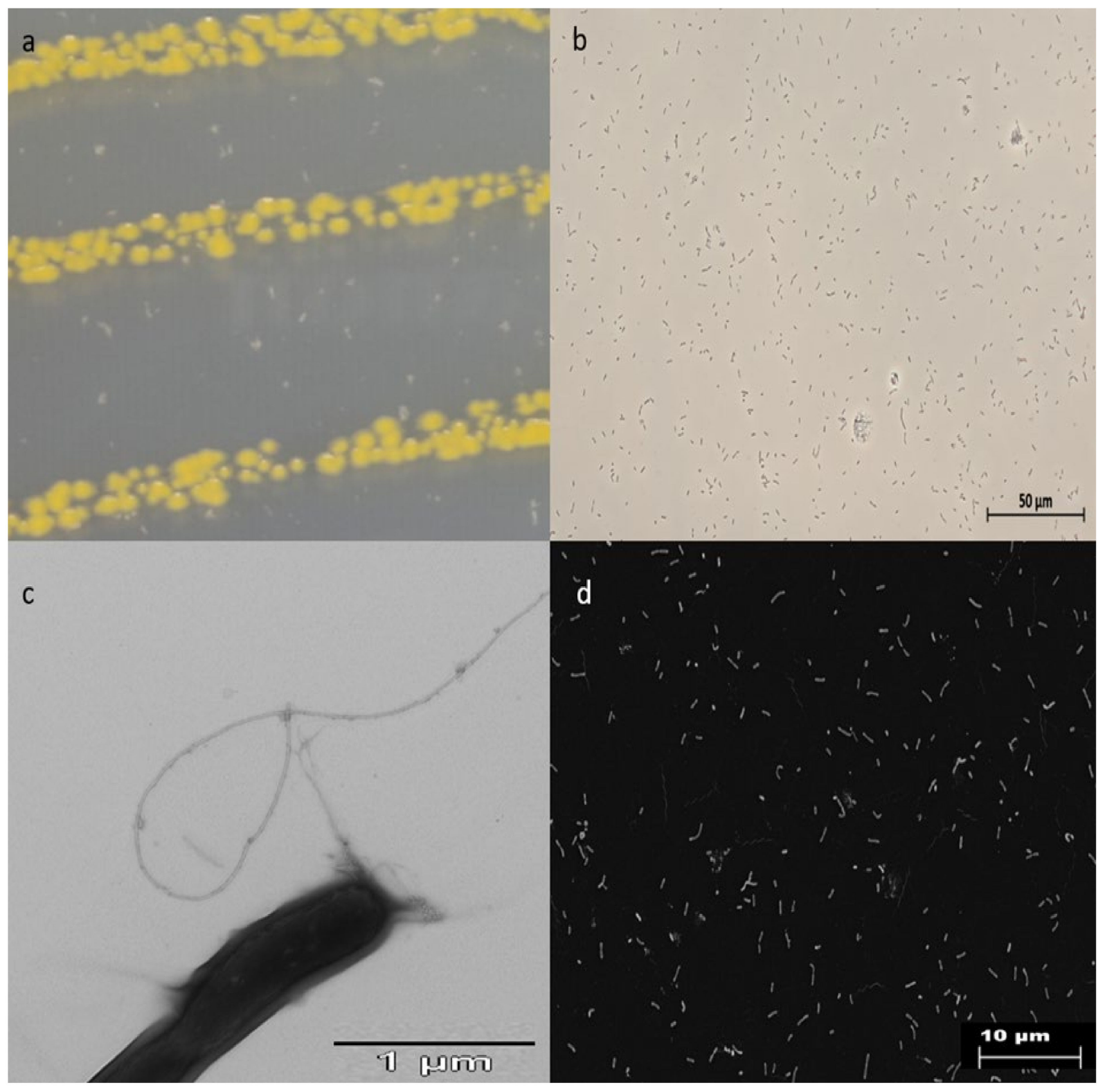

Figure 1. (a) Growth of strain NZ-12B $\mathrm{B}^{\mathrm{T}}$ on marine agar after three days. (b) Phase contrast microscopy of strain NZ-12B (bar $50 \mu \mathrm{m}$ ). (c) Transmission electron microscope (TEM) image of negatively stained cells of NZ-12B ${ }^{\mathrm{T}}$ showing the presence of a single flagellum $(1 \mu \mathrm{m})$. (d) Scanning electron micrograph (SEM) of cells grown on marine agar (bar $10 \mu \mathrm{m})$ depicting rod-shaped morphology. 


\section{2. $16 S$ rRNA Gene-Based Phylogenetic Analysis}

16S rRNA gene sequence analysis is a primary marker for deducing taxonomic relationships. The almost full-length $16 \mathrm{~S}$ rRNA gene sequence of strain NZ-12B ${ }^{\mathrm{T}}$ (1422 nucleotides) was subjected to comparative analysis. Sequence similarity comparisons of 16S rRNA gene using the EzTaxon database [39] revealed that the strain NZ-12B ${ }^{\mathrm{T}}$ was most closely related to A. lutimaris S-5 $5^{\mathrm{T}}(98.58 \%)$, Q. pelagi UST081027-248 ${ }^{\mathrm{T}}(96.44 \%)$, and Q. citreus RE35F $/ 1^{\mathrm{T}}(96.23 \%)$. Because the closely related genus Alteriqipengyuania contains only two species (A. lutimaris and A. halimionae), comparison of $16 \mathrm{~S}$ rRNA sequences was also performed with $A$. halimionae. Strain NZ-12B ${ }^{\mathrm{T}}$ showed $94.78 \% 16 \mathrm{~S}$ rRNA sequence similarity to A. halimionae $\mathrm{CPA} 5^{\mathrm{T}}$. Phylogenetic trees based on an almost complete $16 \mathrm{~S}$ rRNA gene sequence (1422 nucleotides) and inferred from the maximum likelihood (Figure $\mathrm{S} 1$ and neighbor joining methods (Figure 2) showed that strain NZ-12B ${ }^{\mathrm{T}}$ formed a well-defined tight cluster with A. lutimaris $\mathrm{S}-5^{\mathrm{T}}$ supported by a high bootstrap value of $100 \%$. Based on the $16 \mathrm{~S}$ rRNA gene sequence similarities and phylogenetic analysis, $A$. lutimaris KCTC $42109^{\mathrm{T}}$, Q. pelagi JCM $14468^{\mathrm{T}}$, Q. citreus DSM $14432^{\mathrm{T}}$, and A. halimionae $\mathrm{CPA} 5^{\mathrm{T}}$ were selected as the reference strains for comparative analysis.

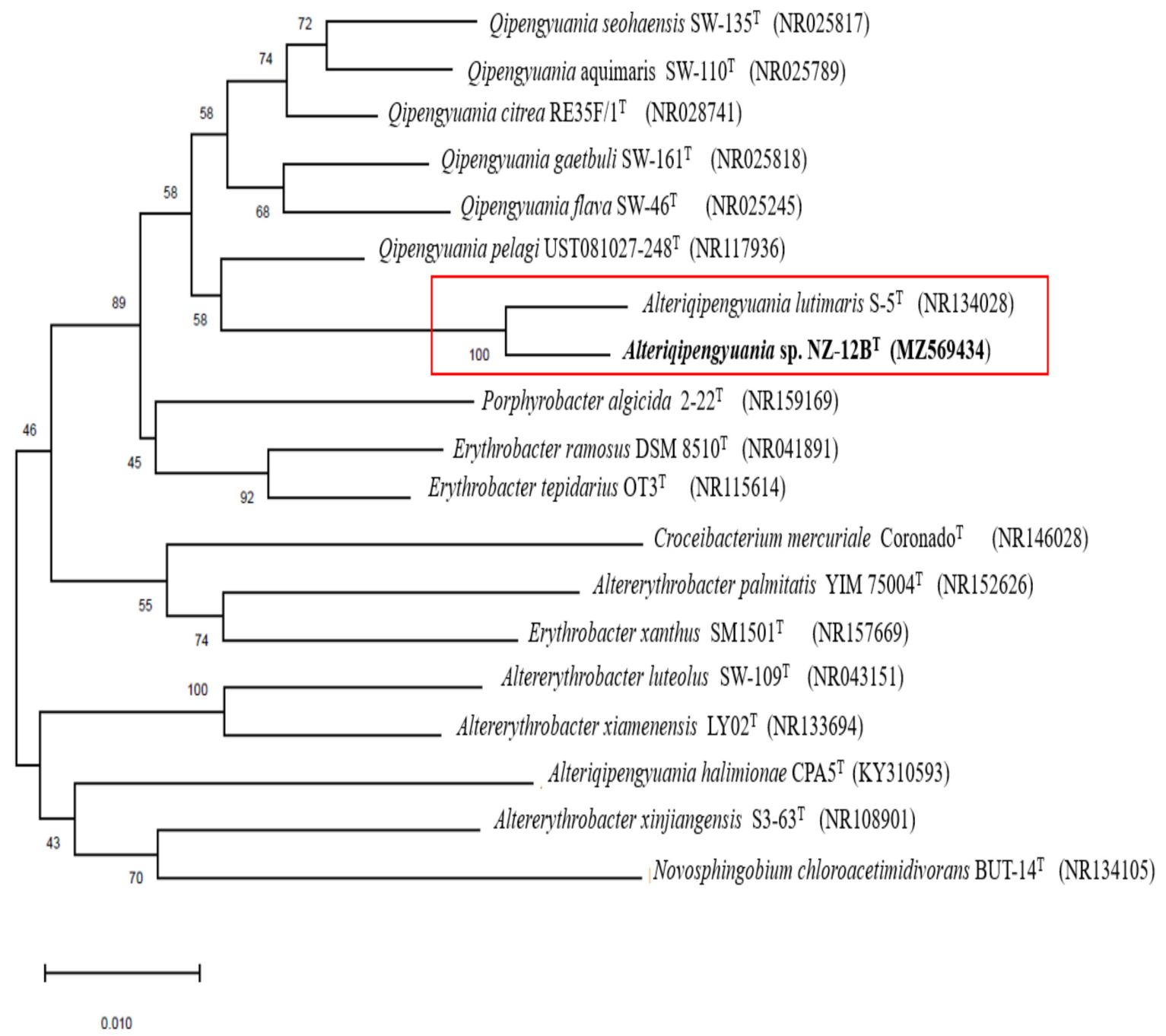

Figure 2. Neighbor joining phylogenetic tree based on almost complete $16 \mathrm{~S}$ rRNA gene sequence of NZ-12B $\mathrm{B}^{\mathrm{T}}$ and its most closely related species. The numbers above the branches are bootstrap support. Bar, 0.010 substitution per nucleotide position. 


\subsection{Chemotaxonomy}

Analyses of the chemical composition of cell constituents of strain NZ-12B ${ }^{\mathrm{T}}$ revealed it possesses chemotaxonomic features that are congruent with those defined for members of the family Erythrobacteraceae [40]. The respiratory quinone profile consisted exclusively of ubiquinone-10 (Q-10), which is in line with the description of the genus Alteriqipengyuania [15]. The polar lipid profile of NZ-12B ${ }^{\mathrm{T}}$ was composed of diphosphatidylglycerol, phosphatidylethanolamine, phosphatidyl-N-methyl-ethanolamine, phosphatidylcholine, sphingoglycolipid, phosphatidylglycerol, one unknown polar lipid, three unknown phospholipid, and three unknown glycolipid (Figure 3). The major fatty acids of strain NZ-12B ${ }^{\mathrm{T}}$ were $\mathrm{C}_{18: 1} \omega 12 \mathrm{t}(41.5 \%), \mathrm{C}_{16: 0}(6.3 \%), \mathrm{C}_{17: 1} \omega 6 \mathrm{c}(22.8 \%)$, and $\mathrm{C}_{14: 0} 2-\mathrm{OH}(5.9 \%)$. The fatty acid profile of strain NZ-12B $\mathrm{B}^{\mathrm{T}}$ and its phylogenetically closest members are presented in Table 1. Differences in the percentages of major fatty acids $C_{18: 1} \omega 12 t, C_{16: 0}$, and $C_{17: 1} \omega 6 c$ distinguish the strain from its close relatives. Ternary solvent extract spectra exhibited a peak at a retention time of $17.80 \mathrm{~min}$ with UV absorption at $425 \mathrm{~nm}$ and an exact mass of 600.41 (the characteristic spectra of xanthophyll-like carotenoids).

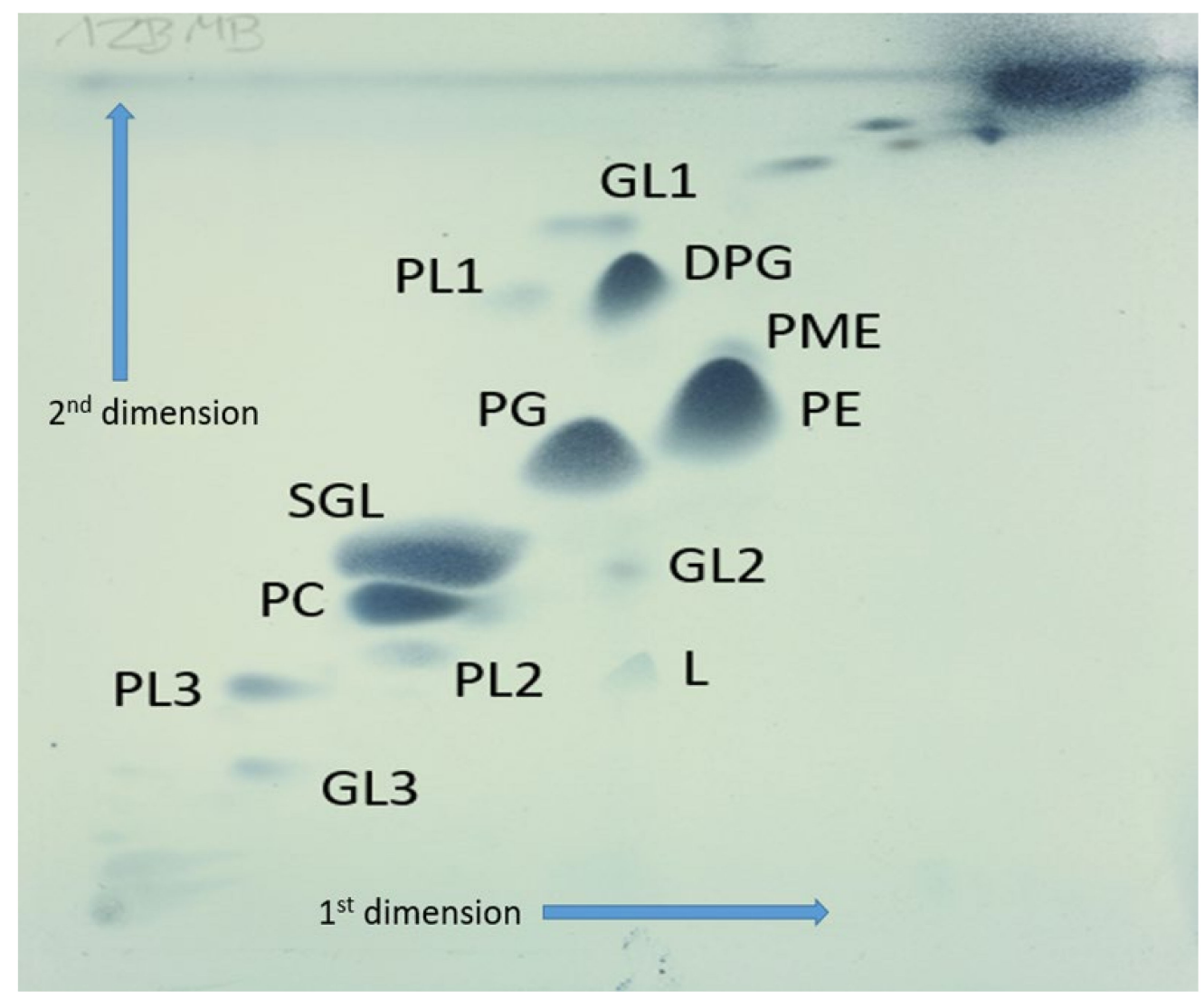

Figure 3. Polar lipids observed in strain NZ-12B ${ }^{T}$ are DPG: diphosphatidylglycerol; PE: phosphatidylethanolamine; PME: phosphatidyl-N-methyl-ethanolamine: PC: phosphatidylcholine; SGL: sphingoglycolipid; PG: phosphatidylglycerol; L: one unknown polar lipid; PL: three unknown phospholipids, and GL: three unknown glycolipids. 
Table 1. Fatty acid profiles of (1) NZ-12B $\mathrm{B}^{\mathrm{T}}$ and the phylogenetically closest relatives; (2) A. lutimaris $\mathrm{S}-5^{\mathrm{T}}$ (data from [6]); (3) Q. citreus RE35F $/ 1^{\mathrm{T}}$; (4) A. halimionae $\mathrm{CPA} 5^{\mathrm{T}}$ (data from [41]); and (5) Q. pelagi UST081027-248 ${ }^{\mathrm{T}}$. Values are percentages of the total fatty acids. The bold type represents the major fatty acids. - , Not detected. TR, Trace amount $(<0.5 \%)$.

\begin{tabular}{|c|c|c|c|c|c|}
\hline Fatty Acids & 1 & 2 & 3 & 4 & 5 \\
\hline \multicolumn{6}{|l|}{ Saturated } \\
\hline C14:0 & 0.70 & 2.9 & - & - & - \\
\hline C15:0 & 1.78 & - & - & 1.6 & 5.76 \\
\hline $\mathrm{C} 16: 0$ & 6.32 & 5.2 & 3.32 & 7.1 & 5.11 \\
\hline C17:0 & 3.56 & 2.1 & 1.93 & 4.7 & 4.63 \\
\hline C18:0 & - & - & - & $\mathrm{TR}$ & - \\
\hline C19:0 & - & - & 1.63 & - & - \\
\hline \multicolumn{6}{|l|}{ Branched } \\
\hline C17:0a & 1.06 & - & 0.78 & - & 3.97 \\
\hline \multicolumn{6}{|l|}{ Unsaturated } \\
\hline$C_{17: 1} \omega 6 c$ & 22.88 & 29.0 & 17.76 & 13.8 & 34.69 \\
\hline$C_{18: 1} \omega 12 t$ & 41.51 & - & - & - & - \\
\hline $\mathrm{C}_{16: 1} \omega 7 \mathrm{c}$ & - & - & 6.75 & - & 3.04 \\
\hline $\mathrm{C}_{16: 1} \omega 7 \mathrm{t}$ & - & - & 1.12 & - & - \\
\hline $\mathrm{C}_{17: 1} \omega 8 \mathrm{c}$ & - & - & 1.69 & 1.5 & - \\
\hline $\mathrm{C}_{18: 1} \omega 7 \mathrm{c}$ & - & - & - & - & 20.92 \\
\hline \multicolumn{6}{|l|}{ Hydroxy } \\
\hline $\mathrm{C}_{14: 0} 2-\mathrm{OH}$ & 5.96 & 4.9 & 3.23 & 2.3 & 4.25 \\
\hline $\mathrm{C}_{15: 0} 2-\mathrm{OH}$ & - & 9.2 & 5.6 & TR & 9.9 \\
\hline $\mathrm{C}_{16: 0} 2-\mathrm{OH}$ & 0.96 & - & 3.77 & - & - \\
\hline 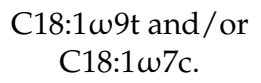 & - & 36.4 & 40.52 & - & - \\
\hline
\end{tabular}

\subsection{Genome Analysis}

The draft assembled genome of strain NZ-12 $\mathrm{B}^{\mathrm{T}}$ was 3,099,119 bp long and consisted of eight contigs with a N50 length of $953,397 \mathrm{bp}$. The DNA G+C content of strain NZ-12B ${ }^{\mathrm{T}}$ was $65.4 \%$, a value in the range reported for members of the genus Alteriqipengyuania, i.e., $63.6-65.5 \mathrm{~mol} \%$ [4]. The genome contained 3054 coding sequences, 50 tRNA genes, six rRNA operons, and a single tmRNA gene after PGAP annotation. The 16S rRNA gene sequence extracted from the genome sequence was in agreement with the partial sequence determined by the PCR method, indicating that the genome sequence was not contaminated. Analysis using the RAST server revealed that only $30 \%$ of the annotated genes were assigned to subsystems (Figure 4). Among the subsystem categories present in the genome, the metabolism of amino acids and derivatives had the highest feature counts (211), followed by protein metabolism, which had 169 feature counts. Thirty-one feature counts were detected for resistance of antibiotic and toxic compounds in the genome of strain $12 \mathrm{~B}^{\mathrm{T}}$, whereas $29,40,15$, and 13 feature counts were present in the genomes of $Q$. pelagi UST081027-248 ${ }^{\mathrm{T}}$, Q. citreus $\mathrm{RE} 35 \mathrm{~F} / 1^{\mathrm{T}}$, A. lutimaris $\mathrm{S}-5^{\mathrm{T}}$, and $A$. halimionae $\mathrm{CPA} 5^{\mathrm{T}}$, respectively, for the said property. 04 feature counts were present in the genome of strain $\mathrm{NZ}-12 \mathrm{~B}^{\mathrm{T}}$ for isoprenoids for quinones, 21 feature counts for fatty acid metabolism, and three for multidrug resistance efflux pumps, whereas four, 17 , and three genes were detected in the genome of A. lutimaris S-5 ${ }^{\mathrm{T}}$ for quinone biosynthesis, fatty acid metabolism, and multidrug resistance efflux pumps, respectively. The characteristic genes and gene 
products present in strain NZ-12B ${ }^{\mathrm{T}}$ were investigated via RAST analysis (Figure 4). Strain $\mathrm{NZ}-12 \mathrm{~B}^{\mathrm{T}}$ contained proteins involved in the metabolism of proteins, biosynthesis of amino acids, and metabolism of fatty acids, lipids, isoprenoids, and proteins related to motility, vitamins, pigments, and chemotaxis. With respect to ecology, gene products related to the resistance of antibiotic and toxic compounds such as copper, cobalt, and mercury were present. Underlying genes related to deep-sea survival were deciphered. Strain NZ-12B ${ }^{T}$ contained genes for trehalose biosynthesis, aspartate-semialdehyde dehydrogenase, flagellar biosynthesis, and resistance to antibiotics. Trehalose is a sugar molecule also known as mycose. It is a cryoprotectant for bacterial cells and used as an energy source [42]. Its presence can provide the ability to manage the cold environment in deep-sea environments. Flagellar motility is very important to allow bacteria to move and acquire nutrients in deep-sea environments. Aspartate-semialdehyde dehydrogenase is involved in the biosynthesis of amino acids. Its expression is regulated by high pressure. Thus, asd gene expression, controlled by high pressure in deep-sea bacteria, seems to be one of the striking mechanisms for survival in the deep-sea environment [43] (Table 2). The antiSMASH server predicted one secondary metabolite biosynthetic gene cluster displaying 33\% similarity to the terpene biosynthetic gene cluster (Figure S2).
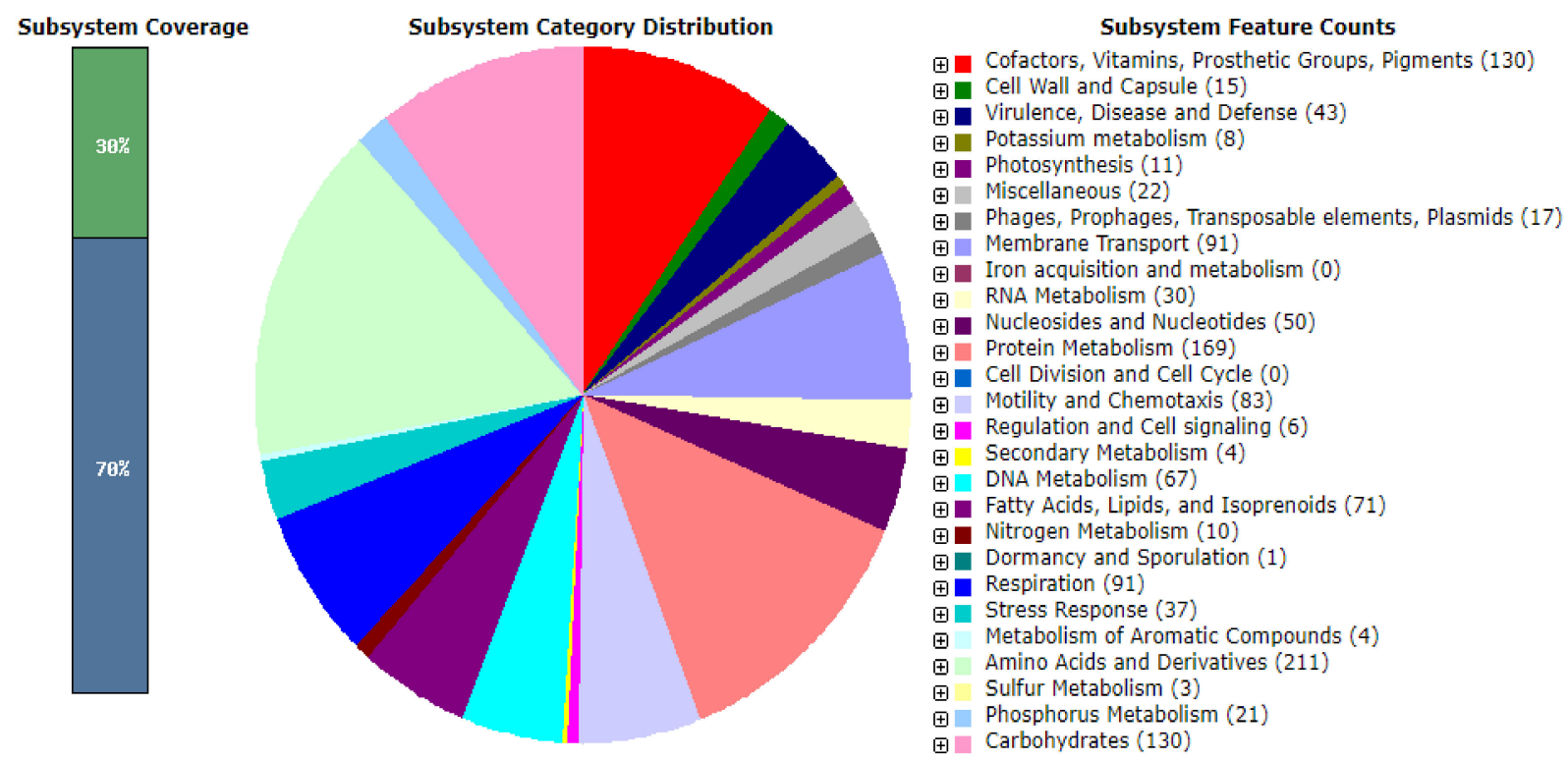

Figure 4. Subsystem category distribution of strain NZ-12B ${ }^{\mathrm{T}}$ based on the RAST annotation server (https:/ / rast.nmpdr.org/) (accessed on 21 August 2021).

Table 2. Characteristic gene products related to deep-sea survival present in the genome of strain NZ-12B ${ }^{\mathrm{T}}$.

\begin{tabular}{|c|c|c|c|}
\hline Category & Subcategory & Subsystem & Role \\
\hline Carbohydrate Metabolism & Di- and oligosaccharides & Trehalose Biosynthesis & $\begin{array}{c}\text { Trehalose-6-phosphate } \\
\text { phosphatase (EC 3.1.3.12) }\end{array}$ \\
\hline $\begin{array}{l}\text { Biosynthesis of amino acids } \\
\text { ans derivates }\end{array}$ & $\begin{array}{l}\text { Lysine, threonine, methionine } \\
\text { and cystine. }\end{array}$ & $\begin{array}{l}\text { Lysine biosynthesis DAP } \\
\text { pathway }\end{array}$ & $\begin{array}{c}\text { Aspartate-semialdehyde } \\
\text { dehydrogenase (EC 1.2.1.11) }\end{array}$ \\
\hline Motility and Chemotaxis & Prokaryotic flagellar motility & Flagellar motility & $\begin{array}{c}\text { Flagellar biosynthesis protein } \\
\text { FliR }\end{array}$ \\
\hline \multirow[t]{2}{*}{$\begin{array}{l}\text { Virulence, Disease and } \\
\text { Defense }\end{array}$} & $\begin{array}{l}\text { Resistance to antibiotics and } \\
\text { toxic compounds }\end{array}$ & $\begin{array}{l}\text { Multidrug Resistance Efflux } \\
\text { Pumps }\end{array}$ & $\begin{array}{l}\text { Multidrug and toxin extrusion } \\
\text { (MATE) family }\end{array}$ \\
\hline & $\begin{array}{l}\text { Resistance to antibiotics and } \\
\text { toxic compounds }\end{array}$ & $\begin{array}{l}\text { Cobalt-zinc-cadmium } \\
\text { resistance }\end{array}$ & $\begin{array}{l}\text { Cobalt-zinc-cadmium } \\
\text { resistance protein CzcA }\end{array}$ \\
\hline
\end{tabular}


A phylogenomic tree generated with the TYGS server exhibited that the strain NZ$12 \mathrm{~B}^{\mathrm{T}}$ formed a well-supported monophyletic clade with A. lutimaris $\mathrm{S}-5^{\mathrm{T}}$, supported by a high bootstrap value of $98 \%$ (Figure 5), which confirmed the result obtained from the phylogenetic analysis of the $16 \mathrm{~S}$ rRNA gene sequences. Through wide genome-based investigation, the taxonomy of the family Erythrobactereacea was recently revised, resulting in the placement of E. lutimaris into a novel genus, Alteriqipengyuania, which is clearly mirrored in the phylogenomic tree. Pairwise ANI values between genome sequence of strain NZ-12B ${ }^{\mathrm{T}}$ and the closest phylogenetic relatives A. lutimaris $\mathrm{S}-5^{\mathrm{T}}$, Q. pelagi UST081027$248^{\mathrm{T}}$, Q. citreus $\mathrm{RE} 35 \mathrm{~F} / 1^{\mathrm{T}}$, and A. halimionae $\mathrm{CPA} 5^{\mathrm{T}}$ were $82.1 \%, 75.1 \%, 74.03 \%$, and $74.5 \%$. respectively; these values are well below the cut-off value of $95 \%-96 \%$ recommended for species delineation (Table 3 ). The $\mathrm{dDDH}$ values between strain NZ-12B ${ }^{\mathrm{T}}$ and strains $A$. lutimaris S-5 ${ }^{\mathrm{T}}$, Q. pelagi $\mathrm{UST} 081027-248^{\mathrm{T}}$, Q. citreus $\mathrm{RE} 35 \mathrm{~F} / 1^{\mathrm{T}}$, and $A$. halimionae CPA5 ${ }^{\mathrm{T}}$ were $19.9 \%, 20.1 \%, 19.7 \%$, and $20.3 \%$, respectively, (Table 3 ) values well below the cut-off value of $70 \%$ for the species boundary.

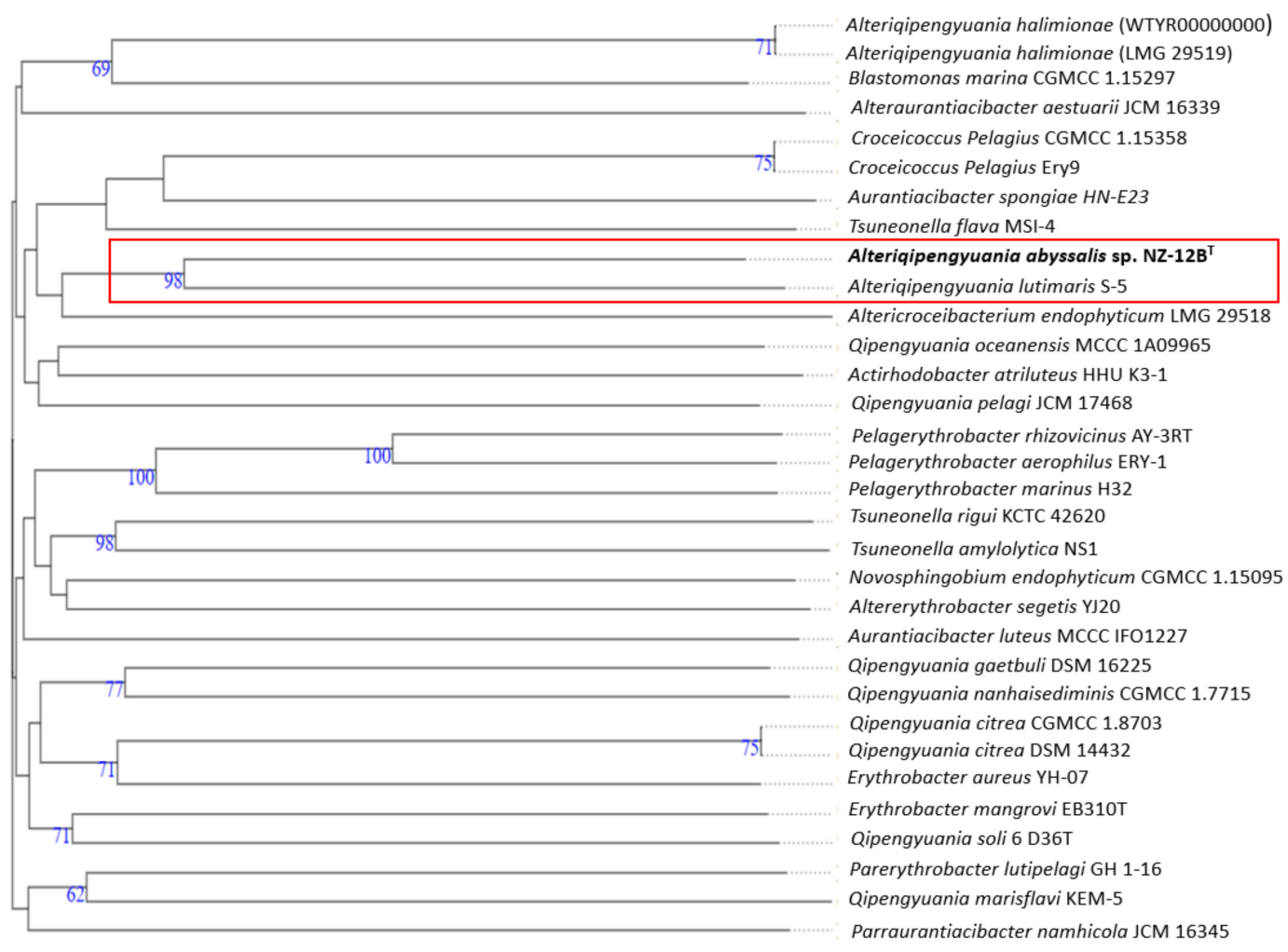

Figure 5. Tree inferred with FastME 2.1.6.1 [44] from GBDP distances calculated from genome sequences of strain NZ$12 \mathrm{~B}^{\mathrm{T}}$. The branch lengths are scaled in terms of GBDP distance formula $d 5$. The numbers above branches are GBDP pseudo-bootstrap support values $>60 \%$ from 100 replications. The tree was rooted at the midpoint.

Table 3. ANI and dDDH values of NZ-12B ${ }^{\mathrm{T}}$ and its closely related phylogenetic strains.

\begin{tabular}{|c|c|c|c|}
\hline Reference Type Strains & $16 S$ & ANI & dDDH \\
\hline A. lutimaris $\mathrm{S}-5^{\mathrm{T}}$ & 98.58 & 82.18 & 19.90 \\
\hline Q. pelagi UST081027-248 & 96.44 & 75.17 & 20.10 \\
\hline Q. citreus $\mathrm{RE} 35 \mathrm{~F} / 1^{\mathrm{T}}$ & 96.23 & 74.03 & 19.7 \\
\hline Q. gaetbuli SW-161 ${ }^{\mathrm{T}}$ & 95.77 & 74.50 & 19.5 \\
\hline Q. flavus SW- $46^{\mathrm{T}}$ & 95.63 & 74.25 & 20.30 \\
\hline A. halimionae $C P A 5^{T}$ & 94.78 & 74.51 & 20.30 \\
\hline
\end{tabular}


Detailed differential properties that distinguish strain NZ-12B ${ }^{\mathrm{T}}$ from its closely related phylogenetic neighbors are given in Table 4 . In view of these combined morphological, chemotaxonomic, and phylogenetic analyses, strain NZ-12B ${ }^{\mathrm{T}}$ warrants classification in the genus Alteriqipengyuania. The level of DNA-DNA relatedness and phenotypic characteristics confirmed that the strain constitutes a separate species. Therefore, based on the data presented, we propose to include strain $\mathrm{NZ}-12 \mathrm{~B}^{\mathrm{T}}$ in the genus Alteriqipengyuania as Alteriqipengyuania abyssalis sp. nov.

Table 4. Differential characteristics of strain NZ-12B ${ }^{\mathrm{T}}$ and closely related type strains.

\begin{tabular}{|c|c|c|c|c|c|}
\hline Characteristics & 1 & 2 & 3 & 4 & 5 \\
\hline Motility & + & - & - & - & + \\
\hline Esterase (C 4) & $\mathrm{W}+$ & - & $\mathrm{w}+$ & + & + \\
\hline Esterase lipase (C 8) & $\mathrm{W}+$ & - & + & + & + \\
\hline Cystine arylamidase & + & $\mathrm{W}+$ & $\mathrm{W}+$ & $\mathrm{w}+$ & $\mathrm{W}+$ \\
\hline Trypsin & + & - & $\mathrm{w}+$ & + & $\mathrm{w}+$ \\
\hline$\alpha$-chymotrypsin & + & + & + & - & + \\
\hline Naphthol-AS-BI-phosphohydrolase & + & + & $\mathrm{w}+$ & + & + \\
\hline N-acetyl- $\beta$-glucosaminidase & - & + & - & - & $\mathrm{ND}$ \\
\hline lysine decarboxylase & $\mathrm{w}+$ & ND & - & - & ND \\
\hline Citrate utilization & $\mathrm{W}+$ & $\mathrm{ND}$ & - & - & $\mathrm{ND}$ \\
\hline Tryptophan deaminase & $\mathrm{w}+$ & ND & + & + & ND \\
\hline Gelatinase & + & - & $\mathrm{W}+$ & - & $\mathrm{ND}$ \\
\hline Nitrate reduction & - & $\mathrm{ND}$ & - & - & - \\
\hline Esculin hydrolysis & + & $\mathrm{ND}$ & + & + & + \\
\hline Mucic acid & - & $\mathrm{w}+$ & - & + & $\mathrm{ND}$ \\
\hline Acetoacetic acid & + & - & + & $\mathrm{W}+$ & $\mathrm{ND}$ \\
\hline Polar lipids & $\begin{array}{c}\text { DPG, PC, SGL, } \\
\text { PG, L, PL1-3, } \\
\text { GL1-3, PE, } \\
\text { PME }\end{array}$ & $\begin{array}{c}\text { * DPG, PG, PC, } \\
\text { SGL, GL, } \\
\text { L1-3 }\end{array}$ & $\begin{array}{l}* * \text { DPG, PC, PE, } \\
\text { PG,2L,1 unknown } \\
\text { pigmented lipid P. }\end{array}$ & $\begin{array}{l}* * * \text { PE, PG, } \\
\text { DPG, PC, } \\
\text { SGL }\end{array}$ & $\begin{array}{c}* * * * \text { PE, } \\
\text { GL1-2, PL1-4. }\end{array}$ \\
\hline \multicolumn{6}{|l|}{ Fatty acids } \\
\hline$C_{17: 1} \omega 6 c$ & $22.88 \%$ & $29.0 \%$ & $34.69 \%$ & $17.76 \%$ & $7.66 \%$ \\
\hline $\mathrm{C}_{14: 0} 2-\mathrm{OH}$ & $5.96 \%$ & $4.9 \%$ & $4.25 \%$ & $3.23 \%$ & $5.89 \%$ \\
\hline
\end{tabular}

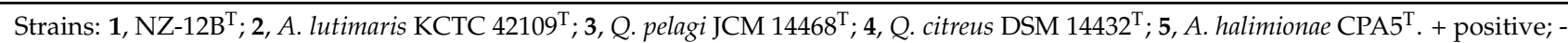
negative; w+ weakly positive; ND; not determined. DPG; diphosphatidylglycerol, PE, phosphatidylethanolamine; PC, phosphotidylcholine; SGL, sphingoglycolipid; PG, phosphotidylglycerol; L, Unknown polar lipid; PL, unknown phospholipid; GL, unknown glycolipid and PG, phosphatidylglycerol. *All data are from this study except polar lipids type strains data marked with *,**,** and ${ }^{* * *}$ are from previous studies. * Data from [6], ${ }^{* *}$ Data from [19]; ${ }^{* *}$ Data from [9]; *** Data from [41].

\section{Emended Description of the Genus Alteriqipengyuania}

The description of the genus is as emended by $\mathrm{Xu}$ et al. (2020), with the exception that the major fatty acids $(>10 \%)$ were C17:1 $\omega 6 \mathrm{c}$ and C18:1 $\omega 12 \mathrm{t}$. The major polar lipids include phosphatidylethanolamine and phosphatidyl-N-methyl-ethanolamine. Positive for $\alpha$-glucosidase.

\section{Description of Alteriqipengyuania abyssalis sp. nov.}

A. abyssalis (a.bys'sa.lis. L. n. abyssus, an abyss, deep-sea abyssalis) pertaining to the abyssal depths of the ocean. Cells are Gram-negative, aerobic, motile, and rod-shaped. Colonies on MA are smooth, circular, and opaque with entire margins, yellow-colored and $1.0-1.2 \mathrm{~mm}$ in diameter at $30{ }^{\circ} \mathrm{C}$ for three days. Flagellum present. Carotenoids pro- 
duced. Growth occurs at $15-37{ }^{\circ} \mathrm{C}$ (optimum $15-30{ }^{\circ} \mathrm{C}$ ), at pH 6-9 (optimum pH 6) and in $0-7.5 \% \mathrm{NaCl}$ (optimum $2.5 \%(w / v) \mathrm{NaCl}$ ). Positive for oxidase and catalase activity. Nitrate is not reduced. Production of $\mathrm{H}_{2} \mathrm{~S}$, indole and acetoin are negative. The enzyme reactions for alkaline phosphatase, leucine arylamidase, valine arylamidase, cystine arylamidase, trypsin, acid phosphatase, naphthol-AS-BI-phosphohydrolase, $\alpha$ - glucosidase, arginine dihydrolase, esculin hydrolysis are positive. Negative for $\alpha$-galactosidase, $\beta$-galactosidase, $\beta$-glucuronidase, $\beta$-glucosidase, $N$-acetyl- $\beta$-glucosaminidase, $\alpha$ - mannosidase, $\alpha$-fucosidase, $\beta$-galactosidase (ONPG), ornithine decarboxylase and urease. Dextrin, turanose, $\alpha$-D-lactose, $\beta$-methyl-D-glucoside, D-salicin, N-acetyl- $\beta$-d-mannosamine, N-acetyl-D-galactosamine, $\mathrm{N}$ acetylneuraminic acid, D-galactose, D-fucose, L-fucose, D-arabitol, glycerol, D-fructose-6-PO4, L-arginine, L-aspartic acid, L-glutamic acid, L-pyroglutamic acid, lincomycin, D-galacturonic acid, L-galactonic acid lactone, D-gluconic acid, D-glucuronic acid, glucuronamide, mucic acid, quinic acid, D-saccharic acid, D-lactic acid methyl ester, L-lactic acid, $\alpha$-keto-glutaric acid, L-malic acid, Tween 40, $\beta$-hydroxy-d, L-butyric acid and acetic acid can be used as sole carbon sources. The chief fatty acids of strain NZ-12B ${ }^{T}$ are $C_{18: 1} \omega 12 t, C_{16: 0}, C_{17: 1} \omega 6 c$, and $\mathrm{C}_{14: 0} 2-\mathrm{OH}$. The polar lipid profile of $\mathrm{NZ}-12 \mathrm{~B}^{\mathrm{T}}$ is composed of diphosphatidylglycerol, phosphatidylethanolamine, phosphatidyl-N-methyl-ethanolamine, phosphatidylcholine, sphingoglycolipid, phosphatidylglycerol, one unknown polar lipid, three unknown phospholipids, and three unknown glycolipids. The respiratory quinone is ubiquinone-10 (Q-10). The $\mathrm{G}+\mathrm{C}$ content is $65.4 \%$.

The type strain NZ-12B ${ }^{\mathrm{T}}\left(=\mathrm{DSM} 112810 ;=\mathrm{NCCB} 100841^{\mathrm{T}}\right)$ was isolated from a sponge sample. The GenBank/EMBL/DDBJ accession numbers for the 16S rRNA gene sequence and whole-genome shotgun project of strain NZ-12B ${ }^{\mathrm{T}}$ are MZ569434 and JAHWXP000000000, respectively.

\section{Conclusions}

Cultural, morphological, and chemotaxonomic markers, in addition to phylogenomic tree analysis, revealed that strain NZ-12B ${ }^{\mathrm{T}}$ belongs to the genus Alteriqipengyuania. The strain could be distinguished from the closely related type strains by several striking characteristics. Based on study using the polyphasic approach, we propose to include strain NZ-12B ${ }^{\mathrm{T}}$ in the genus Alteriqipengyuania as Alteriqipengyuania abyssalis sp. nov.

Supplementary Materials: The following are available online at https: / www.mdpi.com/article/ 10.3390/d13120670/s1, Table S1: Physiological and biochemical characteristics of NZ-12B ${ }^{\mathrm{T}}$ and reference strains on API ZYM strip system. Table S2: Physiological and biochemical characteristics of NZ-12B $\mathrm{B}^{\mathrm{T}}$ and reference strains on API 20E strip system. Table S3: Physiological and biochemical characteristics of NZ-12B ${ }^{\mathrm{T}}$ and reference strains on API20NE strip system. Table S4: Physiological and biochemical characteristics of NZ-12B ${ }^{\mathrm{T}}$ on Biolog Gen III Microplate. Figure S1: Maximum-likelihood phylogenetic tree based on almost complete $16 \mathrm{~S}$ rRNA gene sequence of strain NZ-12B ${ }^{\mathrm{T}}$ and its most closely related species Figure S2: Predicted secondary metabolite gene cluster for strain NZ-12B ${ }^{T}$ identified by analysis of the NZ-12B ${ }^{\mathrm{T}}$ genome sequence with the bioinformatics tool antiSMASH 5.0.

Author Contributions: Conceptualization, S.T.; performed experiments, data analyses, manuscript drafting. C.R.; edited manuscript. M.M.; performed electron microscopy. J.W.; supervision, edited manuscript. All authors have read and agreed to the published version of the manuscript.

Funding: This research received no external funding.

Institutional Review Board Statement: Not applicable.

Data Availability Statement: Strain NZ-12B ${ }^{\mathrm{T}}$ is deposited at the German collection of microorganisms and cell cultures (DSMZ) and the Netherlands culture collection of bacteria (NCCB) under accession no. 112810 and 100841 respectively.

Acknowledgments: The authors thanks Stephanie Schulz for excellent technical assistance, Aileen Gollasch for recording the GC data and Ina Schleicher for electron microscopy sample preparation.

Conflicts of Interest: The authors declare no conflict of interest. 


\section{References}

1. Neill, J. Tackling Drug-Resistant Infections Globally: Final Report and Recommendations the Review on Antimicrobial Resistance; Government of the United Kingdom: London, UK, 2016.

2. Miethke, M.; Pieroni, M.; Weber, T.; Brönstrup, M.; Hammann, P.; Halby, L.; Arimondo, P.B.; Glaser, P.; Aigle, B.; Bode, H.B.; et al. Towards the Sustainable Discovery and Development of New Antibiotics. Nat. Rev. Chem. 2021, 5, 726-749. [CrossRef]

3. Tortorella, E.; Tedesco, P.; Esposito, F.P.; January, G.G.; Fani, R.; Jaspars, M.; de Pascale, D. Antibiotics from Deep-Sea Microorganisms: Current Discoveries and Perspectives. Mar. Drugs 2018, 16, 355. [CrossRef] [PubMed]

4. Xu, L.; Sun, C.; Fang, C.; Oren, A.; Xu, X.W. Genomic-Based Taxonomic Classification of the Family Erythrobacteraceae. Int. J. Syst. Evol. Microbiol. 2020, 70, 4470-4495. [CrossRef] [PubMed]

5. Shiba, T.; Simidu, U. Erythrobacter Longus Gen. Nov., Sp. Nov., an Aerobic Bacterium Which Contains Bacteriochlorophyll A. Int J. Syst. Bacteriol. 1982, 32, 211-217. [CrossRef]

6. Jung, Y.-T.; Park, S.; Lee, J.-S.; Yoon, J.-H. Erythrobacter lutimaris sp. nov., isolated from a tidal flat sediment. Int. J. Syst. Evol. Microbiol. 2014, 64 Pt 12, 4184-4190. [CrossRef] [PubMed]

7. Parte, A.C. LPSN_List of Prokaryotic Names with Standing in Nomenclature (Bacterio.Net), 20 Years On. Int. J. Syst. Evol. Microbiol. 2018, 68, 1825-1829. [CrossRef] [PubMed]

8. Zhuang, L.; Lin, B.; Xu, L.; Li, G.; Wu, C.J.; Luo, L. Erythrobacter spongiae sp. nov., isolated from marine sponge. Int. J. Syst. Evol. Microbiol. 2019, 69, 1111-1116. [CrossRef]

9. Denner, E.B.M.; Vybiral, D.; Koblízek, M.; Kämpfer, P.; Busse, H.-J.; Velimirov, B. Erythrobacter citreus sp. nov., a yellow-pigmented bacterium that lacks bacteriochlorophyll $a$, isolated from the western mediterranean sea. Int. J. Syst. Evol. Microbiol. 2002, 52, 1655-1661. [CrossRef]

10. Lei, X.; Zhang, H.; Chen, Y.; Li, Y.; Chen, Z.; Lai, Q.; Zhang, J.; Zheng, W.; Xu, H.; Zheng, T. Erythrobacter luteus sp. nov., isolated from mangrove sediment. Int. J. Syst. Evol. Microbiol. 2015, 65, 2472-2478. [CrossRef]

11. Fang, C.; Wu, Y.-H.; Sun, C.; Wang, H.; Cheng, H.; Meng, F.-X.; Wang, C.-S.; Xu, X.-W. Erythrobacter zhengii sp. nov., a bacterium isolated from deep-sea sediment. Int. J. Syst. Evol. Microbiol. 2018, 69, 241-248. [CrossRef]

12. Subhash, Y.; Tushar, L.; Sasikala, C.; Ramana, C.V.; Ch Ramana, C.V. Erythrobacter odishensis sp. nov. and Pontibacter odishensis sp. nov. isolated from dry soil of a solar saltern. Int. J. Syst. Evol. Microbiol. 2013, 63, 4524-4532. [CrossRef] [PubMed]

13. Xing, T.; Liu, Y.; Wang, N.; Xu, B.; Liu, K.; Shen, L.; Gu, Z.; Guo, B.; Zhou, Y.; Liu, H. Erythrobacter arachoides sp. nov., isolated from ice core. Int. J. Syst. Evol. Microbiol. 2017, 67, 4235-4239. [CrossRef] [PubMed]

14. Park, S.; Won, S.M.; Yoon, J.H. Erythrobacter marisflavi sp. nov., isolated from estuary water. Int. J. Syst. Evol. Microbiol. 2019, 69, 2696-2702. [CrossRef]

15. Tonon, L.A.C.; Moreira, A.P.B.; Thompson, F. The Family Erythrobacteraceae. In The Prokaryotes: Alphaproteobacteria and Betaproteobacteria; Springer: Berlin/Heidelberg, Germany, 2014; Volume 9783642301, pp. 213-235. [CrossRef]

16. Hosoya, S.; Arunpairojana, V.; Suwannachart, C.; Kanjana-Opas, A.; Yokota, A. Aureispira marina gen. nov., sp. nov., a gliding, arachidonic acid-containing bacterium isolated from the southern coastline of thailand. Int. J. Syst. Evol. Microbiol. 2006, 56, 2931-2935. [CrossRef]

17. Landwehr, W.; Kämpfer, P.; Glaeser, S.P.; Rückert, C.; Kalinowski, J.; Blom, J.; Goesmann, A.; Mack, M.; Schumann, P.; Atasayar, E.; et al. Taxonomic Analyses of Members of the Streptomyces cinnabarinus Cluster, Description of Streptomyces cinnabarigriseus sp. nov. and Streptomyces davaonensis sp. nov. Int. J. Syst. Evol. Microbiol. 2018, 68, 382-393. [CrossRef] [PubMed]

18. Goldberg, S.R.; Correa, H.; Haltli, B.A.; Kerr, R.G. Fulvivirga aurantia sp. nov. and Xanthovirga aplysinae gen. nov., sp. nov., marine bacteria isolated from the sponge Aplysina fistularis, and Emended Description of the Genus Fulvivirga. Int. J. Syst. Evol. Microbiol. 2020, 70, 2766-2781. [CrossRef]

19. Wu, H.X.; Lai, P.Y.; Lee, O.O.; Zhou, X.J.; Miao, L.; Wang, H.; Qian, P.Y. Erythrobacter Pelagi Sp. Nov., a Member of the Family Erythrobacteraceae isolated from the red sea. Int. J. Syst. Evol. Microbiol. 2012, 62, 1348-1353. [CrossRef] [PubMed]

20. Mohr, K.I.; Garcia, R.O.; Gerth, K.; Irschik, H.; Müller, R. Sandaracinus Amylolyticus gen. nov., sp. nov., a starch-degrading soil myxobacterium, and description of Sandaracinaceae fam. nov. Int. J. Syst. Evol. Microbiol. 2012, 62, 1191-1198. [CrossRef]

21. Hall, T. BioEdit: A User-Friendly Biological Sequence Alignment Editor and Analysis Program for Windows 95/98/NT. Nucleic Acids Symp. Ser. 1999, 41, 95-98.

22. Meier-Kolthoff, J.P.; Auch, A.F.; Klenk, H.P.; Göker, M. Genome Sequence-Based Species Delimitation with Confidence Intervals and Improved Distance Functions. BMC Bioinform. 2013, 14, 60. [CrossRef]

23. Meier-Kolthoff, J.P.; Hahnke, R.L.; Petersen, J.; Scheuner, C.; Michael, V.; Fiebig, A.; Rohde, C.; Rohde, M.; Fartmann, B.; Goodwin, L.A.; et al. Complete Genome Sequence of DSM 30083T, the Type Strain (U5/41T) of Escherichia coli, and a Proposal for Delineating Subspecies in Microbial Taxonomy. Stand. Genom. Sci. 2014, 9, 2. [CrossRef]

24. Edgar, R.C. MUSCLE: Multiple Sequence Alignment with High Accuracy and High Throughput. Nucleic Acids Res. 2004, 32, 1792-1797. [CrossRef]

25. Stamatakis, A. RAxML Version 8: A Tool for Phylogenetic Analysis and Post-Analysis of Large Phylogenies. Bioinformatics 2014, 30, 1312-1313. [CrossRef]

26. Goloboff, P.A.; Farris, J.S.; Nixon, K.C. TNT, a Free Program for Phylogenetic Analysis. Cladistics 2008, 24, 774-786. [CrossRef]

27. Pattengale, N.D.; Alipour, M.; Bininda-Emonds, O.R.P.; Moret, B.M.E.; Stamatakis, A. How Many Bootstrap Replicates Are Necessary? J. Comput. Biol. 2010, 17, 337-354. [CrossRef] [PubMed] 
28. Kumar, S.; Stecher, G.; Li, M.; Knyaz, C.; Tamura, K. MEGA X: Molecular Evolutionary Genetics Analysis across Computing Platforms. Mol. Biol. Evol. 2018, 35, 1547-1549. [CrossRef] [PubMed]

29. Minnikin, D.E.; O’Donnell, A.G.; Goodfellow, M.; Alderson, G.; Athalye, M.; Schaal, A.; Parlett, J.H. An Integrated Procedure for the Extraction of Bacterial Isoprenoid Quinones and Polar Lipids. J. Microbiol. Methods 1984, 2, 233-241. [CrossRef]

30. Bóna-Lovász, J.; Bóna, A.; Ederer, M.; Sawodny, O.; Ghosh, R. A Rapid Method for the Extraction and Analysis of Carotenoids and Other Hydrophobic Substances Suitable for Systems Biology Studies with Photosynthetic Bacteria. Metabolites 2013, 3, $912-930$. [CrossRef]

31. Risdian, C.; Landwehr, W.; Rohde, M.; Schumann, P.; Hahnke, R.L.; Spröer, C.; Bunk, B.; Kämpfer, P.; Schupp, P.J.; Wink, J. Streptomyces bathyalis sp. nov., an actinobacterium isolated from the sponge in a deep sea. Antonie van Leeuwenhoek 2021, 114, 425-435. [CrossRef]

32. Wick, R.R.; Judd, L.M.; Gorrie, C.L.; Holt, K.E. Unicycler: Resolving Bacterial Genome Assemblies from Short and Long Sequencing Reads. PLoS Comput. Biol. 2017, 13, e1005595. [CrossRef]

33. Tatusova, T.; DiCuccio, M.; Badretdin, A.; Chetvernin, V.; Nawrocki, E.P.; Zaslavsky, L.; Lomsadze, A.; Pruitt, K.D.; Borodovsky, M.; Ostell, J. NCBI Prokaryotic Genome Annotation Pipeline. Nucleic Acids Res. 2016, 44, 6614-6624. [CrossRef]

34. Lee, I.; Chalita, M.; Ha, S.M.; Na, S.I.; Yoon, S.H.; Chun, J. ContEst16S: An Algorithm That Identifies Contaminated Prokaryotic Genomes Using 16S RNA Gene Sequences. Int. J. Syst. Evol. Microbiol. 2017, 67, 2053-2057. [CrossRef]

35. Aziz, R.K.; Bartels, D.; Best, A.; DeJongh, M.; Disz, T.; Edwards, R.A.; Formsma, K.; Gerdes, S.; Glass, E.M.; Kubal, M.; et al. The RAST Server: Rapid Annotations Using Subsystems Technology. BMC Genom. 2008, 9, 1-15. [CrossRef]

36. Medema, M.H.; Blin, K.; Cimermancic, P.; De Jager, V.; Zakrzewski, P.; Fischbach, M.A.; Weber, T.; Takano, E.; Breitling, R. AntiSMASH: Rapid Identification, Annotation and Analysis of Secondary Metabolite Biosynthesis Gene Clusters in Bacterial and Fungal Genome Sequences. Nucleic Acids Res. 2011, 39 (Suppl. 2), W339-W346. [CrossRef]

37. Blin, K.; Shaw, S.; Steinke, K.; Villebro, R.; Ziemert, N.; Lee, S.Y.; Medema, M.H.; Weber, T. AntiSMASH 5.0: Updates to the Secondary Metabolite Genome Mining Pipeline. Nucleic Acids Res. 2019, 47, W81-W87. [CrossRef]

38. Meier-Kolthoff, J.P.; Göker, M.; Spröer, C.; Klenk, H.P. When Should a DDH Experiment Be Mandatory in Microbial Taxonomy? Arch. Microbiol. 2013, 195, 413-418. [CrossRef] [PubMed]

39. Yoon, S.H.; Ha, S.M.; Kwon, S.; Lim, J.; Kim, Y.; Seo, H.; Chun, J. Introducing EzBioCloud: A Taxonomically United Database of 16S RRNA Gene Sequences and Whole-Genome Assemblies. Int. J. Syst. Evol. Microbiol. 2017, 67, 1613-1617. [CrossRef]

40. Kosako, Y.; Yabuuchi, E.; Naka, T.; Fujiwara, N.; Kobayashi, K. Proposal of Sphingomonadaceae fam. nov., consisting of Sphingomonas Yabuuchi et Al. 1990, Erythrobacter Shiba and Shimidu 1982, Erythromicrobium Yurkov et Al. 1994, Porphyrobacter Fuerst et Al. 1993, Zymomonas Kluyver and van Niel 1936, and Sandaracinobac. Microbiol. Immunol. 2000, 44, 563-575. [CrossRef] [PubMed]

41. Fidalgo, C.; Rocha, J.; Martins, R.; Proença, D.N.; Morais, P.V.; Henriques, I.; Alves, A. Altererythrobacter halimionae sp. nov. and Altererythrobacter endophyticus sp. nov., Two Endophytes from the Salt Marsh Plant Halimione portulacoides. Int. J. Syst. Evol. Microbiol. 2017, 67, 3057-3062. [CrossRef]

42. Kikawada, T.; Saito, A.; Kanamori, Y.; Nakahara, Y.; Iwata, K.I.; Tanaka, D.; Watanabe, M.; Okuda, T. Trehalose Transporter 1, a Facilitated and High-Capacity Trehalose Transporter, Allows Exogenous Trehalose Uptake into Cells. Proc. Natl. Acad. Sci. USA 2007, 104, 11585. [CrossRef] [PubMed]

43. Kato, C.; Smorawinska, M.; Li, L.; Horikoshi, K. Comparison of the Gene Expression of Aspartate /2-D-Semialdehyde Dehydrogenase at Elevated Hydrostatic Pressure in Deep-Sea Bacteria 1. J. Biochem. 1997, 121, 717-723. [CrossRef] [PubMed]

44. Lefort, V.; Desper, R.; Gascuel, O. FastME 2.0: A Comprehensive, Accurate, and Fast Distance-Based Phylogeny Inference Program. Mol. Biol. Evol. 2015, 32, 2798. [CrossRef] [PubMed] 